\title{
Trampling in a seagrass assemblage: direct effects, response of associated fauna, and the role of substrate characteristics
}

\author{
Caren E. Eckrich*, Jeff G. Holmquist ${ }^{* *}$ \\ Department of Marine Science, University of Puerto Rico at Mayagüez, PO Box 908, Lajas, Puerto Rico 00667, USA
}

\begin{abstract}
Human wading in shallow coastal waters is a common activity that inherently involves trampling of the substrate. An experiment was conducted in Thalassia testudinum seagrass beds in Puerto Rico to determine how seagrass and associated mobile fauna respond to this anthropogenic disturbance. Three trampling intensities were applied to replicate seagrass beds throughout a 4 mo period. Seagrass biomass was inversely related to trampling intensity and duration. There was moderate recovery in the trampled areas 7 mo after the last trampling event. Intense levels of trampling resulted in decreased shrimp abundances, especially for Thor manningi. Fish abundances and composition of shrimp and fish assemblages did not change significantly after 4 mo of trampling. T. testudinum beds with softer substrates lost more seagrass biomass as a result of trampling than seagrass beds with firm substrates, suggesting that substrate firmness can modify disturbance effects. Educators and resource managers should limit trampling by large groups, or confine it to small areas with firm substrates, and researchers should be mindful of artifacts arising from trampling in and around sampling areas.
\end{abstract}

KEY WORDS: Trampling · Disturbance - Seagrass · Recovery $\cdot$ Recreation $\cdot$ Thalassia testudinum · Decapods · Fishes

Resale or republication not permitted without written consent of the publisher

\section{INTRODUCTION}

Despite the current surge in outdoor recreation, we know surprisingly little about the most basic consequences of this increased usage. For instance, we are often enjoined to 'take nothing but photos, leave nothing but footprints', but are those footprints really innocuous? In terrestrial assemblages, damage to flora is directly related to the amount of foot traffic (Bayfield 1979, Cole 1995a,b). On rocky shores, trampled areas generally have lower densities and diversities of algae and sessile organisms than less trampled areas (e.g. Addessi 1994, Keough \& Quinn 1998). Trampling experiments on coral

\footnotetext{
*Present address: Sea and Discover, Kaya A. Neumann \#11, Bonaire, Netherlands Antilles

${ }^{* *}$ Corresponding author. Present address: Marine Science Institute, University of California-Santa Barbara, Star Rt. 1, Box 198, Mammoth Lakes, California 93546, USA.

E-mail: holmquis@lifesci.ucsb.edu
}

reef flats resulted in direct breakage and/or mortality of coral colonies, and reduced live coral cover (Woodland \& Hooper 1977, Hawkins \& Roberts 1993).

Unlike terrestrial grasslands, seagrasses have no history of trampling pressure by large herbivores, and therefore may not have the same resistance to trampling as terrestrial flora. Seagrasses grow in saturated substrates, which may make them more prone to trampling damage than terrestrial flora growing in soils that are drier and more compact. Seagrasses also lack certain supportive tissues that are present in many terrestrial grasses (Cronquist 1981).

Although it is known that human trampling reduces cover of plants and sessile fauna, there is little knowledge of effects on mobile fauna associated with trampled vegetation in any system (but see Liddle 1975, Keough \& Quinn 1998, Brown \& Taylor 1999). The high diversity and abundance of animals living within seagrass beds is largely due to habitat selection and the refugium from predation provided by the complexity of the seagrass 
habitat (Stoner \& Lewis 1985, Sogard et al. 1987). Structural complexity and heterogeneity are believed to be the most important factors influencing changes in faunal composition (e.g. Heck \& Orth 1980, Lewis 1984). However, Bell \& Westoby $(1986 a, b)$ found that density of some species of seagrass-associated decapods increased with decreasing seagrass leaf height and density, whereas density of others decreased. Similarly, some studies have found no clear relationship between fish abundances and seagrass cover, leaf height, and density (Bell \& Westoby 1986a,b, Connolly 1994).

An important emphasis of previous work has been the relative resistance of different plant species and growth forms to trampling. In terrestrial habitats, herbaceous plant species that are low-growing, have tough leaves, and form mats or tufts are generally more resistant to trampling than other growth forms (Cole 1995b). Terrestrial grasses are more resistant to trampling than some forest plant species, such as leafy, stemmed forbs (Cole 1985). However, very little is known about how habitat characteristics, such as substrate quality, modify trampling disturbance, although substrate has been suggested as a potentially important factor (Harrison 1980/1981, Hylgaard 1980/1981, Wynberg \& Branch 1997).

This study reports the results of a trampling experiment in seagrass beds at La Parguera, Puerto Rico. We tested the null hypotheses that human trampling does not damage Thalassia testudinum shoots or rhizomes and does not alter the abundance or composition of associated fauna. Further, sediment composition and substrate penetrability were examined as potential modifiers of trampling disturbance. Disturbance regimes have many components/descriptors, including spatial distribution, frequency, area affected, intensity, landscape topography, context, and history (e.g. Connell 1978, Pickett \& White 1985). The experiment was designed with these diverse parameters in mind, and manipulations were based on observed usage patterns.

\section{MATERIALS AND METHODS}

Study area and sampling design. The study area was located near La Parguera (Fig. 1), in southwestern Puerto Rico ( $\left.17^{\circ} 58^{\prime} \mathrm{N}, 67^{\circ} 03^{\prime} \mathrm{W}\right)$. The shallow seagrass beds in the area are composed mainly of Thalassia testudinum, but are sometimes interspersed with, or bordered by, Syringodium filiforme and Halodule wrightii. Calcareous green algae (species of Halimeda, Penicillus, and Udotea) and unattached red and brown algae (particularly species of Acanthophora and Dictyota) are common in the study area. Zoanthids often grow among $T$. testudinum blades, sometimes forming dense mats. Most study sites were located in the lee of coral- reef crests or shallow rubble cays, but several of the sites closer to the coast were near mangrove islands with limited coral-reef development (see Eckrich 1998 for more detailed site description).

The experimental design consisted of 3 experimental trampling 'lanes' at each of 10 sites (Fig. 2). Trampling lanes were used so that the results could be compared with other marine and terrestrial experimental trampling studies (see also Sun \& Walsh 1998, Keough \& Quinn 1998, Schiel \& Taylor 1999). The lanes were wider than some experimental lanes used in terrestrial studies (Cole \& Bayfield 1993) to avoid an edge effect that could have influenced the abundances of mobile fauna. The 10 replicate sites were chosen in seagrass beds of $<1 \mathrm{~m}$ depth where no known trampling had occurred. At each site, the 3 lanes $(5 \times 2.5 \mathrm{~m}$ : control, low-intensity trampling, and high-intensity trampling) were marked with PVC stakes. The lanes were $1.5 \mathrm{~m}$ apart to minimize inter-lane trampling effects.

Sites were selected by identifying widely dispersed, shallow seagrass beds and haphazardly throwing markers into the beds. At 2 of the study sites, strong currents were perpendicular to the trampling lanes. Lane arrangement on these 2 sites was not haphazard; rather, the upcurrent lane was the control, and the lanes to be trampled were staggered so as to minimize sediment transport from one lane to another. Five sites were trampled from March through July 1996, and another 5 sites were trampled from September 1996 through January 1997. Measurements were taken from each lane before trampling, 2 and 4 mo after trampling began, and 7 mo after the last trampling

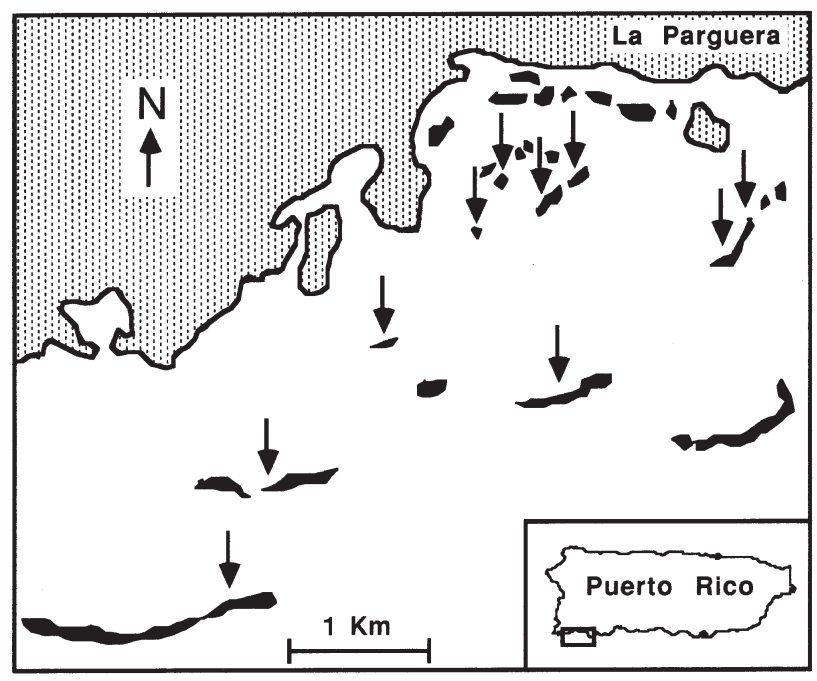

Fig. 1. South coast of Puerto Rico near town of La Parguera. Stippling: 'mainland' Puerto Rico; black shapes: coral reefs and/or mangrove islands with which extensive seagrass meadows are associated. Arrows indicate 10 study sites 


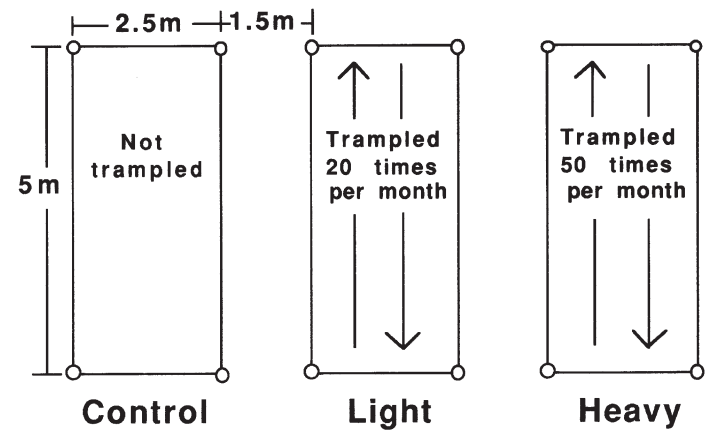

Fig. 2. Treatment lanes: control with no trampling, lightlytrampled lane (trampled 20 times $\mathrm{mo}^{-1}$ for $4 \mathrm{mo}$ ), and heavily-trampled lane (trampled 50 times $\mathrm{mo}^{-1}$ for $4 \mathrm{mo}$ ). Arrows indicate directions of trampling

event (the latter was to assess recovery). We sampled at 2 time periods because the volume of fieldwork prohibited us from sampling all 10 sites simultaneously and because we wished to maximize the general applicability of our results. In other words, our sampling of multiple sites at multiple times was aimed at providing spatial and temporal replication rather than revealing site or seasonal differences per se.

In the low- and high-intensity trampling lanes, a $57 \mathrm{~kg}$ person wearing rubber-soled shoes walked to the end of the lane and back 20 and 50 times, respectively. The trampling was applied evenly across each lane (i.e. the person began trampling back and forth on the left side of the lane and slowly worked back to the right side and so on from one side to the other). Treatments were applied once a month for 4 mo. Trampling intensities and frequencies were based on multi-year departmental records for visitor group usage of shallow seagrass beds (Eckrich 1998). Records included number of groups per year, group size, and duration of grassbed use. Our low- and high-intensity levels of disturbance bracketed the observed level of usage.

Seagrass. During each sampling series, a $1 \mathrm{~m}^{2}$ quadrat was placed near each end of each lane at each study site (avoiding the edges). Within each of these quadrats, the number of short shoots lying within 2 randomly placed $0.063 \mathrm{~m}^{2}(25 \times 25 \mathrm{~cm})$ quadrats was counted to determine short-shoot density. Also, all short shoots within 2 randomly placed $0.016 \mathrm{~m}^{2}$ $(12.5 \times 12.5 \mathrm{~cm})$ quadrats were collected within each of the $1 \mathrm{~m}^{2}$ quadrats. Five short shoots were randomly selected from each of these samples. Number of blades per short shoot, blade lengths and blade widths were measured to calculate leaf-area index (LAI). Calcium carbonate was removed from the photosynthetic material of the samples with a dilute hydrochloric acid solution and gentle scraping (similar to the protocol of Dauby \& Poulicek 1995). Samples were then dried at $90^{\circ} \mathrm{C}$ for $24 \mathrm{~h}$ and weighed to determine standing crop (photosynthetic biomass).
Seven months after the last trampling treatment, short-shoot density, LAI, and canopy height data were collected from each of the 10 sites. Field sampling and laboratory processing were identical to the protocol described above, except that short shoots were counted in 2 (instead of 4) randomly placed $0.063 \mathrm{~m}^{2}$ quadrats and collected from 2 (instead of 4) randomly placed $0.016 \mathrm{~m}^{2}$ quadrats within each trampling lane.

Cover estimates were also obtained. Four quadrats $\left(1 \mathrm{~m}^{2}\right)$ were randomly placed in each lane, and the percent cover of Thalassia testudinum, algae (all species combined), zoanthids, and sand were visually estimated. These data were collected before trampling and 2 and 4 mo after trampling began.

Two rhizome cores were taken from the outside perimeter of each trampling lane before trampling began. The cores were taken from the perimeter because coring within the lanes would have directly affected the experimental area. The holes left from the corer were subsequently plugged with cores from nearby seagrass so that predators such as octopuses and stomatopods would not move into some of the holes and bias the experiment. One month after the last trampling treatment, 2 cores were taken from the middle of each lane to assess trampling disturbance, and the holes were subsequently filled. The cores were collected using a $15 \mathrm{~cm}$ diameter corer that penetrated to an average depth of $25 \mathrm{~cm}$. There was no rhizome development below this depth at the 10 sites studied. Samples were rinsed and sorted in the laboratory, and the non-senescent rhizomes (rootlets not included) were oven-dried at $90^{\circ} \mathrm{C}$ and weighed.

Fauna. Faunal sampling occurred before seagrass sampling at each interval; samples were taken during daylight hours. A $0.56 \mathrm{~m}^{2}(75 \times 75 \mathrm{~cm})$ throw-trap (Kushlan 1981, Holmquist et al. 1989a,b, Rozas \& Minello 1997) with a depth of $50.5 \mathrm{~cm}$ was thrown into the center of each lane and held in place with $2.27 \mathrm{~kg}$ weights on the outside of each trap corner. A $0.75 \mathrm{~m}$ wide bar-seine (a rectangular net with rigid edges and 2 handles) with $2 \mathrm{~mm}$ square mesh was passed through the seagrass canopy within the trap 10 times, and the contents of the seine were emptied into a container between scoops. Live animals were transported to the laboratory and sorted immediately. Species abundances of shrimps and fishes were recorded.

Sediment composition. Two sediment samples were haphazardly collected from each site and separated into 3 categories: mud $(<0.062 \mathrm{~mm})$, sand $(0.062$ to $2 \mathrm{~mm}$ ), and gravel ( $>2 \mathrm{~mm}$ ). Sediment cores to a depth of $15 \mathrm{~cm}$ were collected using a $5.1 \mathrm{~cm}$ diameter PVC corer. In the laboratory, organic particles were dissolved from the samples with a $30 \%$ hydrogen peroxide solution, and the clay portions of each were subsequently separated by wet-sieving with distilled water. 
The clay samples were then dried at $40^{\circ} \mathrm{C}$ and weighed (Folk 1974). The remaining sediments of each sample were also dried at $40^{\circ} \mathrm{C}$, dry-sieved to separate sand and gravel components, and then weighed (Folk 1974).

Substrate penetrability. Substrate penetrability was measured using 2 methods, one to measure penetration as a function of impact, the other to measure penetration as a result of steady pressure. Eight haphazard measurements were taken at each of the study sites using each of the 2 methods. Measurements were taken on the perimeters of the sampling lanes.

The 'impact' method used a speargun (Hawaiian sling). The elastic band of the sling was retracted with a force of $9.5 \mathrm{~kg}$ and, when released, shot the pole spear directly into the substrate. The tip of this impact penetrometer was fitted with a pan-head machine screw $(5 \times 0.8 \mathrm{~cm})$ and held $1 \mathrm{~m}$ above the substrate. Before releasing the elastic band, the penetrometer was fitted into a $2.54 \mathrm{~cm}$ diameter PVC pipe that was perpendicular to the substrate to assure a $90^{\circ}$ angle of impact. After the penetrometer had been released, the distance that the screw penetrated the substrate was measured.

The 'pressure' method used a steady pressure exerted by a rod and measured with a scale. The scale was attached on one end of a $2.4 \mathrm{~m}$ long pipe fitted with a wood cylinder (2.54 cm diameter) at the other end. By pulling down on the scale, a constant force of $9 \mathrm{~kg} \mathrm{~cm}^{-2}$ was applied towards the substrate until the pressure penetrometer stopped sinking. The distance the base penetrated the substrate was then measured.

Data analysis. Before-after, beforeintermediate, and intermediate-after differences between treatments were contrasted for short-shoot density, standing crop, LAI, canopy height, percentage cover, and faunal abundances. Because of high temporal variance, contrasts were made using changes in given measures, during individual time periods. We also report mean values, in addition to tests on changes, because these values are more intuitive and provide additional perspective. No intermediate data were collected for rhizome biomass, and therefore only before-after differences between treatments were contrasted for this variable. Normality was tested for changes in variables using residuals and scatterplots. Equality of variances was tested using F-max and Cochran's tests (Kirk 1982). In order to meet assumptions of normality and homogeneity of variance, various transformations were required. Changes in short-shoot density, leaf-area index, canopy height, and standing crop were log-transformed, and change in percentage cover of seagrass was arcsine-transformed. Changes in shrimp and fish abundances were given transformations of $y^{1 / 2}+(y+1)^{1 / 2}$ and $\log (y+1)$, respectively. Seagrass variables were examined by paired Student's $t$-tests (1-tailed, following significant randomized-block ANOVAs) when assumptions of normality were met, and non-parametric Wilcoxon signed-ranks were performed on contrasts for the remaining variables. Simple chi-square tests were performed on shrimp and fish species abundances. The sequential Bonferroni correction (Holm 1979, Rice 1989) was used to compensate for multiple comparison errors. We also present limited ANOVA results of seasonal differences in trampling impact. However, we believe that our 2 sets of concurrent samples do not allow a robust test of seasonal differences (see the excellent discussion in Morrisey et al. 1992). Linear regressions (one-tailed) were used to investigate the influence of substrate characteristics. All statistical analyses were done using SYSTAT (Wilkinson 1990).
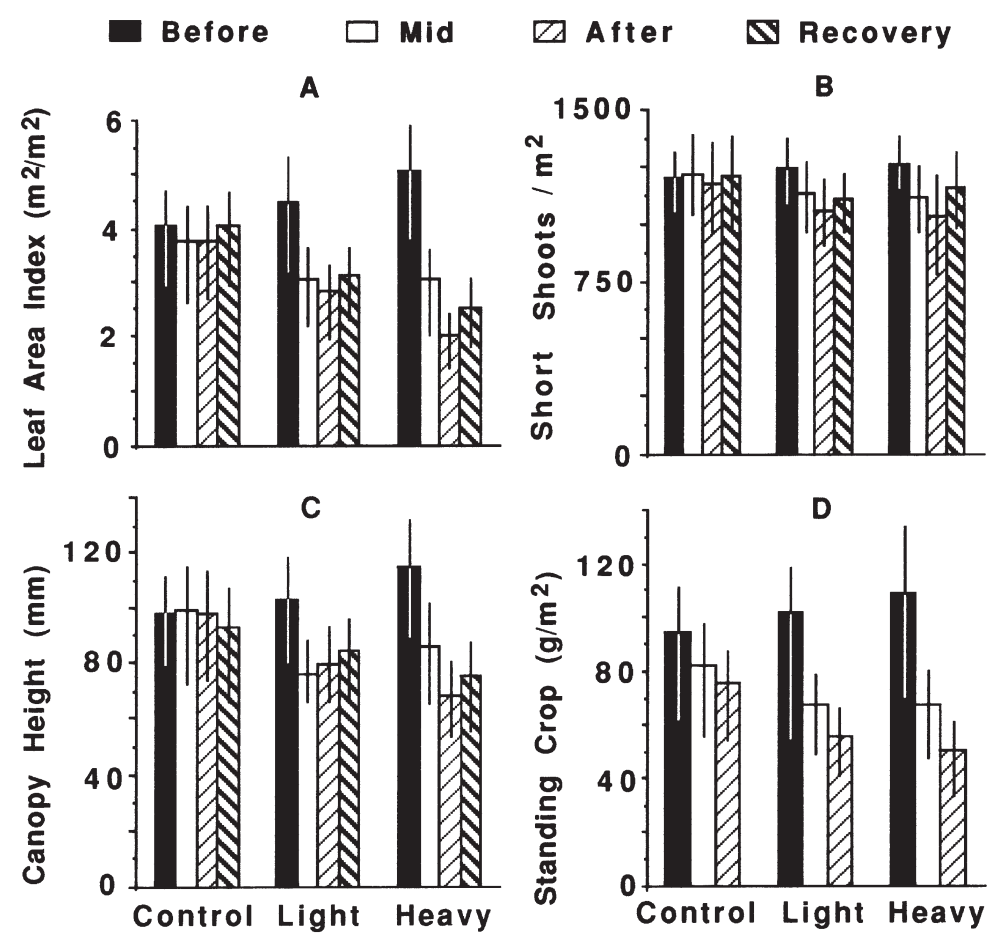

Fig. 3. Leaf area index, short-shoot density, canopy height, and standing crop before (Before), after 2 mo (Mid), after 4 mo (After) trampling, and 7 mo after last trampling treatment (Recovery) for controls, lightly-trampled lanes (20 passes $\mathrm{mo}^{-1}$ ), and heavily-trampled lanes (50 passes $\mathrm{mo}^{-1}$ ). Data are means $\pm 95 \%$ confidence intervals 


\section{RESULTS}

\section{Seagrass}

In general, Thalassia testudinum biomass decreased with increasing trampling intensity and trampling time. After 4 mo of trampling (before-after), LAI, short-shoot density, canopy height, and standing crop all decreased in the heavily-trampled lanes (Fig. 3, Table 1), whereas only canopy height and LAI decreased significantly (after Bonferroni correction) in the lightly-trampled lanes. Declines for these latter variables were greater in the heavily-trampled lanes. Decreases in LAI, short-shoot density, canopy height, and standing crop were greater in spring than in fall ( $\mathrm{p}<0.001$ for all; $F=33.5,19.2,33.7$, and 33.7, respectively).

Trampling resulted in decreased seagrass and increased sand cover (Fig. 4, Table 1). After 4 mo of trampling (before-after), percentage cover of seagrass decreased in both types of trampled lanes and declined more in the heavily-trampled lanes than in the lightlytrampled lanes (Fig. 4, Table 1). Percentage cover of sand increased in the heavily-trampled lanes and, to a lesser extent, in the lightly-trampled lanes (Fig. 4, Table 1); 2 of the 10 heavily-trampled lanes developed large sand patches. Algal cover was unaffected (Fig. 4, Table 1).
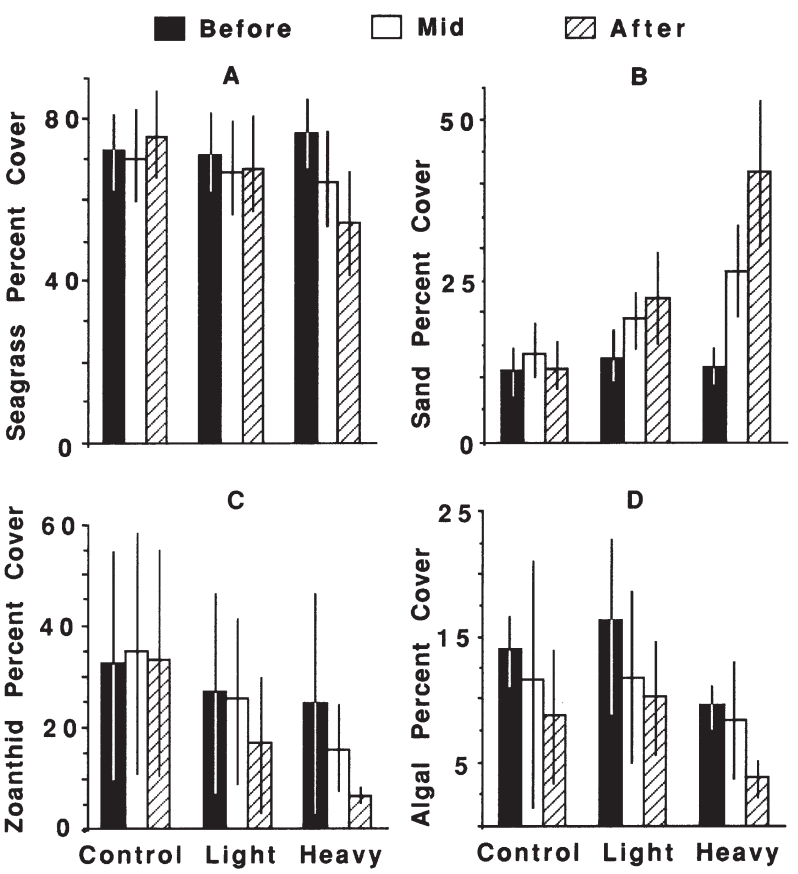

Fig. 4. Percentage cover of seagrass, sand, zoanthids, and macroalgae before (Before), after 2 mo (Mid), and after 4 mo (After) trampling for controls, lightly-trampled lanes (20 passes $\mathrm{mo}^{-1}$ ), and heavily-trampled lanes (50 passes mo ${ }^{-1}$ ). Zoanthids were present at 3 sites, and algae were present at 5 sites. Data are means $\pm 95 \%$ confidence intervals
Table 1. Changes in seagrass meadows as a function of trampling intensity. Each p-value is result of 1-tailed Student's $t$-test comparing changes during a certain time interval in a given measure for a pair of treatments (C: control lanes; L: lightly-trampled lanes; $\mathrm{H}$ : heavily-trampled lanes): e.g. first $\mathrm{p}$-value in table indicates that change in leaf-area index during first 2 mo of study differed between control and heavilytrampled plots *Significant at per-contrast error rate [alpha $=$ $0.05]_{i}{ }^{* *}$ significant after correcting for multiple comparisons. See Figs. 3 to 8 for details of changes. na: not applicable

\begin{tabular}{|c|c|c|c|c|}
\hline Comparison & $0-2 \mathrm{mo}$ & $2-4 \mathrm{mo}$ & $0-4 \mathrm{mo}$ & $4-11 \mathrm{mo}$ \\
\hline \multicolumn{5}{|c|}{ Leaf-area index } \\
\hline $\mathrm{C}$ vs $\mathrm{H}$ & $0.003^{* *}$ & $0.008^{* *}$ & $0.001^{* *}$ & $0.118^{* *}$ \\
\hline C vs L & $0.005^{* *}$ & 0.134 & $0.002^{* *}$ & $0.420^{* *}$ \\
\hline L vs H & $0.047^{*}$ & 0.077 & $0.001^{* *}$ & $0.169^{* *}$ \\
\hline \multicolumn{5}{|c|}{ Short-shoot density } \\
\hline $\mathrm{C}$ vs $\mathrm{H}$ & $0.015^{*}$ & 0.082 & $0.003^{* *}$ & $0.023^{*}$ \\
\hline C vs L & $0.036^{*}$ & 0.411 & $0.046^{*}$ & $0.345^{*}$ \\
\hline L vs $H$ & 0.375 & 0.149 & 0.126 & 0.021 \\
\hline \multicolumn{5}{|c|}{ Canopy height } \\
\hline $\mathrm{C}$ vs $\mathrm{H}$ & $0.009^{*}$ & $0.010^{*}$ & $0.001^{* *}$ & 0.067 \\
\hline C vs L & $0.023^{*}$ & 0.431 & $0.002^{* *}$ & 0.159 \\
\hline L vs $\mathrm{H}$ & 0.338 & $0.043^{*}$ & $0.001^{* *}$ & 0.363 \\
\hline \multicolumn{5}{|c|}{ Standing crop } \\
\hline $\mathrm{C}$ vs H & $0.012^{*}$ & 0.072 & $0.002^{* *}$ & na \\
\hline C vs L & 0.160 & $0.031^{*}$ & $0.023^{*}$ & na \\
\hline L vs $\mathrm{H}$ & 0.059 & 0.145 & $0.019^{*}$ & na \\
\hline \multicolumn{5}{|c|}{ Seagrass cover } \\
\hline $\mathrm{C}$ vs H & $0.006^{* *}$ & $0.003^{* *}$ & $0.001^{* *}$ & na \\
\hline C vs L & $0.041^{*}$ & $0.001^{* *}$ & $0.007^{* *}$ & na \\
\hline L vs $H$ & $0.018^{*}$ & $0.027^{*}$ & $0.009^{* *}$ & na \\
\hline \multicolumn{5}{|l|}{ Sand cover } \\
\hline $\mathrm{C}$ vs $\mathrm{H}$ & $0.011^{*}$ & $0.003^{* *}$ & $0.002^{* *}$ & na \\
\hline C vs L & $0.025^{*}$ & $0.019^{*}$ & $0.010^{*}$ & na \\
\hline L vs H & $0.017^{*}$ & $0.004^{* *}$ & $0.009^{*}$ & na \\
\hline \multicolumn{5}{|c|}{ Zoanthid cover } \\
\hline $\mathrm{C}$ vs $\mathrm{H}$ & 0.137 & 0.051 & 0.055 & na \\
\hline C vs L & 0.137 & $0.034^{*}$ & $0.034^{*}$ & na \\
\hline L vs $\mathrm{H}$ & 0.137 & 0.446 & 0.233 & na \\
\hline \multicolumn{5}{|l|}{ Algal cover } \\
\hline $\mathrm{C}$ vs $\mathrm{H}$ & 0.272 & 0.072 & 0.342 & na \\
\hline C vs L & 0.433 & 0.459 & 0.232 & na \\
\hline L vs $\mathrm{H}$ & 0.433 & 0.233 & 0.173 & na \\
\hline \multicolumn{5}{|c|}{ Rhizome biomass } \\
\hline $\mathrm{C}$ vs H & na & na & $0.046^{*}$ & na \\
\hline C vs L & na & na & 0.142 & na \\
\hline L vs $\mathrm{H}$ & na & na & 0.069 & na \\
\hline \multicolumn{5}{|c|}{ No. of shrimps } \\
\hline $\mathrm{C}$ vs $\mathrm{H}$ & 0.100 & 0.073 & $0.001^{* *}$ & na \\
\hline C vs L & 0.162 & $0.015^{*}$ & $0.039^{*}$ & na \\
\hline L vs $\mathrm{H}$ & 0.406 & 0.453 & 0.351 & na \\
\hline \multicolumn{5}{|l|}{ No. of fishes } \\
\hline $\mathrm{C}$ vs H & 0.058 & 0.183 & 0.332 & na \\
\hline C vs L & 0.099 & 0.228 & 0.263 & na \\
\hline L vs H & 0.269 & 0.320 & 0.220 & na \\
\hline
\end{tabular}




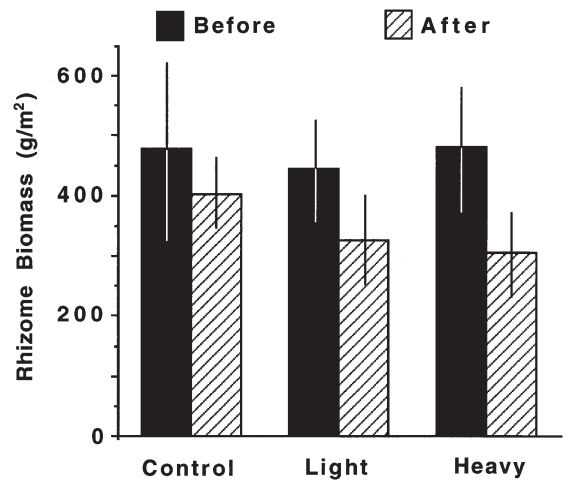

Fig. 5. Thalassia testudinum. Rhizome biomass before (Before) and after 4 mo (After) trampling for controls, lightly-trampled lanes (20 passes $\left.\mathrm{mo}^{-1}\right)$, and heavily-trampled lanes (50 passes $\mathrm{mo}^{-1}$ ). Data are means $\pm 95 \%$ confidence intervals

Rhizome biomass decreased in the heavily-trampled lanes (Fig. 5, Table 1). Study sites lost between 0 and $72 \%$ of rhizome biomass (except one site with a $5 \%$ increase) and between 0 and $81 \%$ of standing crop (one increased by $23 \%$ ) in the heavily-trampled lanes.

The plots did not completely recover to pre-experiment conditions in the 7 mo following the last trampling treatment. Leaf area index, short-shoot density, and canopy height of the trampled lanes were still below the levels of the controls and the pre-trampling levels of the treatment lanes. At several of the study sites, the reduced seagrass cover in the heavilytrampled lanes was visually distinguishable from the surrounding seagrass 14 mo after trampling ended.

\section{Fauna}

A total of 2614 shrimps composed of 18 species, and 175 fishes composed of 11 or more genera (sygnathids were not identified to genus level) were collected across all treatment categories. Ninety-seven percent of the total abundance of shrimps was accounted for by 7 species: Hippolyte zostericola/pleuracanthus (40\%), Thor manningi (23\%), Latreutes fucorum (11\%), Alpheus normanni (10\%), Periclimenes americanus (8\%), Processa bermudensis (3\%), Metapenaeopsis goodei ( $2 \%)$. Ninety-five percent of the total abundance of fishes was accounted for by 4 genera and the sygnathids: Malacoctenus (31.5\%), Sparisoma (31.5\%), Bathygobius (16.4\%), Sygnathidae $(12.1 \%)$, and Haemulon $(3.6 \%)$.

After 4 mo of trampling, shrimp abundances (before-after) decreased in both the heavily- and lightlytrampled lanes (Fig. 6, Tables 2 \& 3), but there were no seasonal effects in trampling response $(F=0.786, \mathrm{p}=$
0.384). Compared with the other shrimp species, the abundance of Thor manningi decreased after 4 mo in the heavily-trampled lanes $\left(\chi^{2}=21.1\right.$, df $=1, p<$ 0.001; Tables $2 \& 3$ ). However, the abundance of Processa bermudensis increased in comparison with the other shrimp species after 4 mo in the heavilytrampled lanes $\left(\chi^{2}=24.8, \mathrm{df}=1, \mathrm{p}<0.001\right.$; Tables 2 \& $3)$. Variance in fish abundance was high, and overall abundances did not change after 4 mo of trampling (Fig. 6, Table 1), nor were there seasonal effects $(F=$ 0.007, $p=0.936)$. In addition, the abundances and percentage composition of individual fish species did not differ significantly among treatments or time intervals (Tables 2, 3). In the controls, shrimp abundances decreased from an average of 72 shrimp $\mathrm{m}^{-2}$ to an average of 41 shrimp $\mathrm{m}^{-2}$ and fish abundances increased from an average of 1.8 fishes $\mathrm{m}^{-2}$ to 3.3 fishes $\mathrm{m}^{-2}$ during the $4 \mathrm{mo}$ of trampling. There was an up to $75 \%$ reduction in zoanthid cover, although variance was high (Fig. 4, Table 1).

\section{Substrate characteristics}

The percentage composition of mud ranged from 4.7 to $33.2 \%$, of sand from 58.4 to $88.4 \%$, and of gravel
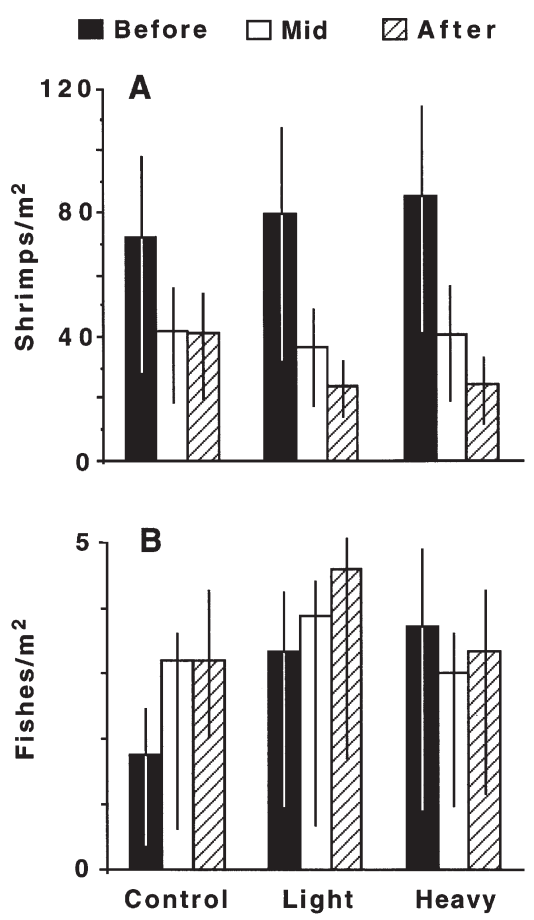

Fig. 6. Shrimp, and fish abundances per square meter seagrass meadow before (Before), after 2 mo (Mid), and after 4 mo (After) trampling for controls, lightly-trampled lanes $\left(20\right.$ passes $\left.\mathrm{mo}^{-1}\right)$, and heavily-trampled lanes $\left(50\right.$ passes $\left.\mathrm{mo}^{-1}\right)$. Data are means $\pm 95 \%$ confidence intervals 
Table 2. Mean (SE) abundances of shrimps and fishes per square meter seagrass meadow before and after trampling

\begin{tabular}{|c|c|c|c|}
\hline Species & Control & Light & Heavy \\
\hline \multicolumn{4}{|l|}{ Shrimps } \\
\hline \multicolumn{4}{|c|}{ Hippolyte zost/pleur a } \\
\hline Before & $34.7(7.1)$ & $26.5(5.5)$ & $31.7(5.7)$ \\
\hline After & $15.7(2.4)$ & $10.5(1.6)$ & $9.8(2.0)$ \\
\hline \multicolumn{4}{|c|}{ Thor manningi } \\
\hline Before & $11.9(2.1)$ & $21.4(5.5)$ & $23.9(4.3)$ \\
\hline After & $10.1(2.2)$ & $2.5(0.6)$ & $1.4(0.5)$ \\
\hline \multicolumn{4}{|c|}{ Latreutes fucorum } \\
\hline Before & $13.9(3.5)$ & $14.2(4.7)$ & $8.9(2.2)$ \\
\hline After & $3.2(0.9)$ & $1.8(0.4)$ & $1.4(0.4)$ \\
\hline \multicolumn{4}{|c|}{ Alpheus normanni } \\
\hline Before & $3.0(0.6)$ & $4.1(0.7)$ & $4.6(1.2)$ \\
\hline After & $5.5(1.1)$ & $4.6(0.8)$ & $3.9(1.0)$ \\
\hline \multicolumn{4}{|c|}{ Periclimenes americanus } \\
\hline Before & $4.1(0.6)$ & $5.3(1.1)$ & $6.1(1.4)$ \\
\hline After & $3.2(0.6)$ & $1.2(0.3)$ & $1.1(0.4)$ \\
\hline \multicolumn{4}{|c|}{ Processa bermudensis } \\
\hline Before & $1.1(0.3)$ & $0.5(0.2)$ & $1.1(0.3)$ \\
\hline After & $0.2(0.1)$ & $1.2(0.5)$ & $2.8(0.9)$ \\
\hline \multicolumn{4}{|c|}{ Metapenaeopsis goodei } \\
\hline Before & $0.7(0.4)$ & $0.2(0.1)$ & $2.5(1.1)$ \\
\hline After & $0.4(0.2)$ & $0.5(0.2)$ & $0.9(0.4)$ \\
\hline \multicolumn{4}{|l|}{ Other } \\
\hline Before & $3.0(0.9)$ & $5.0(1.6)$ & $4.8(0.9)$ \\
\hline After & $3.0(1.0)$ & $3.4(0.4)$ & $2.1(0.1)$ \\
\hline \multicolumn{4}{|l|}{ Fishes } \\
\hline \multicolumn{4}{|c|}{ Malacoctenus spp. } \\
\hline Before & $0.7(0.2)$ & $1.3(0.4)$ & $2.3(0.5)$ \\
\hline After & $1.6(0.4)$ & $1.4(0.4)$ & $1.3(0.3)$ \\
\hline \multicolumn{4}{|c|}{ Sparisoma spp. } \\
\hline Before & $2.1(0.2)$ & $1.8(0.7)$ & $1.4(0.3)$ \\
\hline After & $1.1(0.2)$ & $0.9(0.3)$ & $1.4(0.3)$ \\
\hline \multicolumn{4}{|c|}{ Bathygobius spp. } \\
\hline Before & $0.0(0.0)$ & $0.5(0.2)$ & $0.4(0.2)$ \\
\hline After & $0.5(0.2)$ & $1.1(0.4)$ & $0.7(0.2)$ \\
\hline \multicolumn{4}{|l|}{ Other } \\
\hline Before & $1.1(0.4)$ & $0.7(0.2)$ & $1.4(0.5)$ \\
\hline After & $0.7(0.2)$ & $1.1(0.2)$ & $0.4(0.1)$ \\
\hline \multicolumn{4}{|c|}{$\begin{array}{l}{ }^{\text {a }} \text { Treated as a complex }(\text { zost }=\text { zostericola } ; \text { pleur }=\text { pleura }- \\
\text { canthus })\end{array}$} \\
\hline
\end{tabular}

from 2.5 to $22.6 \%$ at the 10 study sites (Fig. 7). None of the 3 categories of sediment (mud, sand, gravel) were significantly related to any of the seagrass parameters ( $\mathrm{p}$-value ranged from 0.15 , for standing crop/gravel, to 0.99 for $\mathrm{LAI} / \mathrm{mud})$.

Impact penetration averaged between 95 and $435 \mathrm{~mm}$. This measure accounted for $51.1 \%$ of the variability in the percentage change of rhizome biomass $(p=0.01$; Fig. 8) but only $1 \%$ of the variability in the percent change of standing crop $(p=0.39)$. Pressure penetration averaged between 15 and $497 \mathrm{~mm}$, and explained
Table 3. Mean percentage (SE) composition of shrimp and fish assemblages in seagrass meadows before and after trampling

\begin{tabular}{|c|c|c|c|}
\hline Species & Control & Light & Heavy \\
\hline \multicolumn{4}{|l|}{ Shrimps } \\
\hline \multicolumn{4}{|c|}{ Hippolyte zost/pleur ${ }^{\text {a }}$} \\
\hline Before & $27.6(8.2)$ & $29.3(7.6)$ & $30.1(8.4)$ \\
\hline After & $36.4(9.6)$ & $39.3(7.8)$ & $39.3(11.4)$ \\
\hline \multicolumn{4}{|c|}{ Thor manningi } \\
\hline Before & $29.4(7.7)$ & $24.5(6.7)$ & $35.4(10.6)$ \\
\hline After & $17.1(6.6)$ & $7.6(2.7)$ & $4.1(2.0)$ \\
\hline \multicolumn{4}{|c|}{ Latreutes fucorum } \\
\hline Before & $26.6(9.3)$ & $23.5(9.9)$ & $10.8(4.7)$ \\
\hline After & $13.5(6.5)$ & $16.0(7.5)$ & $8.2(4.5)$ \\
\hline \multicolumn{4}{|c|}{ Alpheus normanni } \\
\hline Before & $2.3(0.9)$ & $7.4(4.2)$ & $4.6(2.1)$ \\
\hline After & $20.3(9.6)$ & $17.5(5.8)$ & $12.1(4.0)$ \\
\hline \multicolumn{4}{|c|}{ Periclimenes americanus } \\
\hline Before & $5.1(1.4)$ & $7.3(3.3)$ & $4.6(1.9)$ \\
\hline After & $5.4(1.6)$ & $3.3(1.5)$ & $3.0(1.7)$ \\
\hline \multicolumn{4}{|c|}{ Processa bermudensis } \\
\hline Before & $1.2(0.8)$ & $0.6(0.4)$ & $1.9(1.4)$ \\
\hline After & $0.3(0.3)$ & $2.5(1.7)$ & $9.4(5.8)$ \\
\hline \multicolumn{4}{|c|}{ Metapenaeopsis goodei } \\
\hline Before & $0(0)$ & $0.8(0.8)$ & $3.5(2.4)$ \\
\hline After & $0(0)$ & $0(0)$ & $3.5(3.1)$ \\
\hline \multicolumn{4}{|l|}{ Other } \\
\hline Before & $7.8(2.4)$ & $6.6(2.0)$ & $9.1(2.9)$ \\
\hline After & $7.1(3.6)$ & $13.8(2.2)$ & $20.4(9.7)$ \\
\hline \multicolumn{4}{|l|}{ Fishes } \\
\hline \multicolumn{4}{|c|}{ Malacoctenus spp. } \\
\hline Before & $11.6(7.2)$ & $26.9(15.3)$ & $38.3(15.4)$ \\
\hline After & $29.6(13.3)$ & $29.0(13.2)$ & $25.9(13.4)$ \\
\hline \multicolumn{4}{|c|}{ Sparisoma spp. } \\
\hline Before & $71.6(17.4)$ & $26.9(14.7)$ & $35.8(15.3)$ \\
\hline After & $30.6(14.3)$ & $21.0(11.4)$ & $32.3(12.3)$ \\
\hline \multicolumn{4}{|c|}{ Bathygobius spp. } \\
\hline Before & $0(0)$ & $15.9(14.1)$ & $8.3(8.3)$ \\
\hline After & $9.3(4.7)$ & $25.0(13.4)$ & $27.8(14.7)$ \\
\hline \multicolumn{4}{|l|}{ Other } \\
\hline Before & $16.6(10.5)$ & $30.1(18.1)$ & $17.5(8.5)$ \\
\hline After & $30.6(14.3)$ & $25.0(11.2)$ & $13.9(11.1)$ \\
\hline
\end{tabular}

$54.1 \%$ of the variability in the percentage change of rhizome biomass ( $p=0.0075$; Fig. 8), but explained only $12.5 \%$ of the variability in the percentage change of standing crop $(\mathrm{p}=0.16)$.

\section{DISCUSSION}

Human trampling negatively affects terrestrial plants, and we found that trampling similarly reduced the leaf area index, short-shoot density, canopy height, stand- 


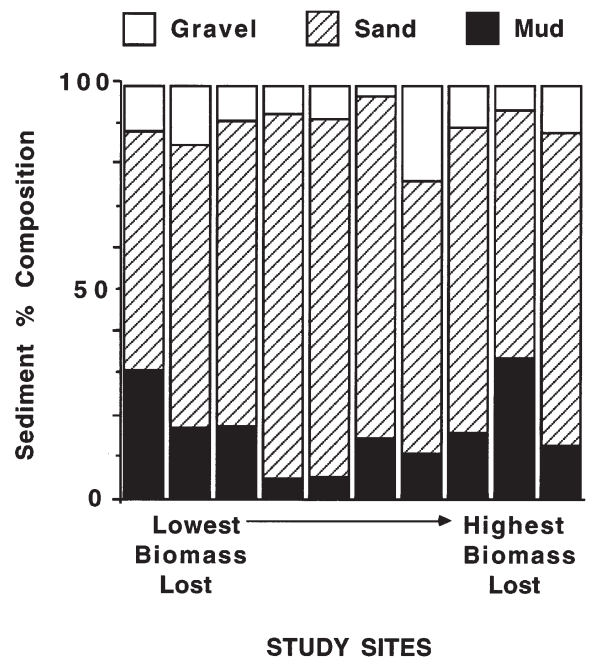

Fig. 7. Percentage composition of gravel, sand, and mud across sites relative to spectrum of seagrass (Thalassia testudinum) biomass lost

ing crop, and cover of marine meadows. Intense levels of trampling also resulted in reduced rhizome biomass, a measure that, to our knowledge has not been examined in previous human trampling studies. The amount of damage to Thalassia testudinum from trampling is relatively proportional to the intensity and duration of
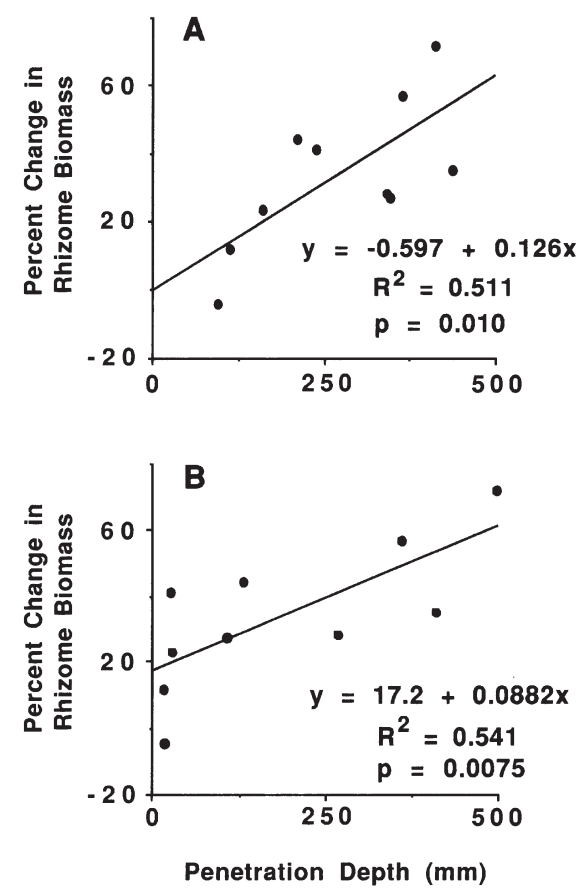

Fig. 8. Thalassia testudinum. Percent change in rhizome biomass as a function of substrate penetrability, measured with impact (A) and pressure (B) penetrometers foot traffic, which is also true for some plants in both marine and terrestrial assemblages (Taylor et al. 1993, Schiel \& Taylor 1999).

Seagrasses may be less resistant to trampling than terrestrial grasses. Although Thalassia testudinum is grazed by manatees, sea turtles, fishes, and urchins (Thayer et al. 1984, Valentine \& Heck 1999), this seagrass has not been subjected to the trampling pressure associated with grazing in terrestrial grasslands. Unlike most terrestrial grasses, T. testudinum does not have sclerenchyma tissue, which helps prevent breakage of rhizomes, roots, and leaves (Cronquist 1981, Raven et al. 1981). In addition, being submerged, $T$. testudinum grows in saturated sediment, which may lead to less resistance to trampling relative to terrestrial grasses growing in relatively dry soils. Susceptibility of grasslands to livestock-trampling is greater in wet soil conditions than in dry soil conditions (Robinson \& Alderfer 1952, Edmond 1966). Substrates saturated with water are generally more easily penetrated than dry substrates, and trampling in saturated substrates is more likely to lead to substrate breakthroughs and subsequent rhizome damage than trampling in dry substrates. Rhizome density may also influence the probability of substrate break-throughs, although we did not collect sufficient data to test this relationship. It has been suggested that very soft sandflats may be more sensitive to the impacts associated with trampling than more compact sandflats (Wynberg \& Branch 1997). In our study, sites that had softer substrates had greater losses in rhizome biomass as a result of trampling. Substrate hardness influences the susceptibility of seagrass to trampling and perhaps other disturbance sources such as propellers and anchors. Habitat factors may also influence the time necessary for recovery of plant assemblages (Harrison 1980/1981, Hylgaard 1980/1981). The present study supports the contention that environmental factors, such as substrate quality, play a role in an organism's response to perturbation (see also e.g. Jans et al. 1993).

The depth of trampling or wading may also be an important factor, perhaps as important as substrate quality, in determining the amount of damage suffered by Thalassia testudinum. Depth is a potentially useful mitigating factor not present in terrestrial assemblages. A person would exert less force on the substrate in $1 \mathrm{~m}$ of seawater than in $50 \mathrm{~cm}$ of seawater because of the buoyancy of the water. Unfortunately, most wading occurs in the shallowest, and probably most vulnerable, areas.

The maximum intensity of use that an area can continue to support under a particular management regime without inducing a major change in the managed area has been termed the 'recreational carrying capacity' (Goldsmith 1974, Sun \& Walsh 1998). Our 
study suggests that even relatively low intensities of trampling may be non-sustainable and therefore exceed the recreational carrying capacity of Thalassia testudinum seagrass beds because of long-lasting negative effects. Although our experiment reproduced the human-disturbance regime observed in Puerto Rico in terms of intensity, area affected, and frequency, each of these parameters can be greater in certain outdoor education settings. For instance, some grassbeds in the Florida Keys receive daily usage by multiple groups (Holmquist pers. obs.). Pickett \& White (1985) suggest that root-biased systems, such as T. testudinum meadows (Williams 1990), are resistant to abovesubstrate disturbances and that damage to belowground components is necessary for substantial changes to these systems. Our experimental treatments caused moderate opening of the rhizome mat. Continued trampling, even at low intensities, may increasingly damage the seagrass and result in sparse seagrass or bare sand. In temperate and sub-tropical regions, where seagrasses experience a shorter growing season and even annual defoliation, the effect of human trampling may be more pronounced than reported in this study. For instance, Valentine \& Heck (1991) and Heck \& Valentine (1995) found that winter defoliation of north Florida T. testudinum was achieved with half the grazing pressure required for summer defoliation (see also Wittmann \& Ott 1982). This differential effect has been attributed to seasonally-insufficient rhizome reserves (Valentine \& Heck 1991, Heck \& Valentine 1995, Valentine et al. 1997 and references therein). Further, effects are likely to vary among species of seagrasses as has been demonstrated for terrestrial plants (Cole 1995b). As an example, Halodule wrightii has much smaller rhizomes and is often associated with shorelines and sediments with large proportions of siltclay. This species may be more susceptible to trampling damage than Thalassia testudinum.

Unlike most previous trampling studies, this study has evaluated the response of mobile fauna to trampling disturbance. Direct trampling effects have been implicated in reductions of sessile invertebrate abundances and cover (Kay \& Liddle 1989, Brosnan \& Crumrine 1994), but indirect effects, via damage to the seagrass canopy, may best explain the observed shifts in the mobile invertebrate assemblage. Epifaunal abundances generally decrease with decreasing structural complexity of seagrasses (Leber 1985, Connolly \& Butler 1996). Decreased grass-shrimp abundances in response to trampling, particularly for Thor manningi, were probably the result of the decrease in seagrass physical complexity. As trampling slowly thinned the seagrass, shrimps probably emigrated to denser seagrass outside the trampling lanes, or failed to immigrate into the trampling lanes rather than suffering direct mortality (see also Holmquist 1997, Keough \& Quinn 1998, Brown \& Taylor 1999). Conversely, shrimps of the family Processidae are often associated with bare patches in seagrass meadows (Holmquist pers. obs.), and this habitat preference may account for the increased abundance and percent composition of Processa bermudensis in response to trampling. Trampling effects on the fish assemblage were not as pronounced. Organisms that are more mobile may be less likely to be sensitive to boundary and patch structure at a given spatial scale (Kareiva 1983, Wiens et al. 1985), and this generalization appears to hold for at least some grassbed fauna (Holmquist 1998). The comparatively mobile fishes using these grassbeds may not respond to the patch scale $(2.5 \times 5 \mathrm{~m}$ lanes $)$ produced by trampling in this study.

The sessile zoanthids lie at the opposite extreme of faunal mobility, and these fauna suffered substantial, though variable, reductions in percent cover. Zoanthid colonies often form a dense matrix of sand bound by closely-spaced body columns, and zoanthid mortality could lead to increased sediment instability.

Human trampling damaged Thalassia testudinum standing crop and rhizomes, and also decreased seagrass-associated shrimp abundances. Importantly, the T. testudinum beds recovered very slowly after trampling, and many trampled lanes were still distinguishable from surrounding seagrass 14 mo after trampling ended. Such a slow recovery has also been noted as a result of other severe disturbance to T. testudinumdominated meadows (e.g. Heck \& Valentine 1995, Holmquist 1997) although small gaps in Halodule wrightii and Zostera capricorni meadows can recover more quickly (Creed \& Amado Filho 1999, Rasheed 1999). Educators and managers can minimize impact with alternatives such as underwater viewers, snorkeling, and interpretive aquaria. If group-wading is unavoidable, we recommend concentrating activities in small areas of thigh-deep seagrass with firm substrate. Recommendations for terrestrial systems include minimizing concentrated trampling in relatively pristine areas (Graydon \& Hanson 1997, Sun \& Walsh 1998). However, given that seagrass beds have a relatively low threshold for damage and long recovery time, concentration of use may be a better strategy. A combination of a short disturbance interval and long recovery time is likely to lead to unstable systems, particularly if such a disturbance regime is of broad spatial extent (Turner et al. 1993).

Although the emphasis of our work was on an evaluation of impact by educational and recreation groups, the results constitute a caveat to researchers. For instance, trampling during emergent throw trapping (versus underwater drop-trapping; Holmquist 1997) in soft sediment can result in 'doughnuts' composed of a 
core of relatively intact seagrass surrounded by a ring of denuded substrate (Holmquist pers. obs. during work reported by Sogard et al. 1987, 1989, Holmquist et al. 1989a,b). Given the slow recovery of Thalassia testudinum from trampling, researchers should try to minimize wading in study areas, in an effort to reduce artifacts, particularly when plots are to be sampled repeatedly.

Acknowledgements. We thank G. Breckon, R. Macchiavelli, M. Nemeth, B. Shank, and P. Yoshioka, and 3 anonymous readers for their review of the manuscript, and A. BowdenKerby, A. Ortiz, A. Uhrin, S. Slade, and particularly J. SchmidtGengenbach for additional discussion and assistance. We also appreciate the helpfulness of the Department of Marine Science staff. This work was supported by funding from The PADI Foundation (to C.E.E.) and U.S. Army Research Office Grants DAAH 04-93-2-0020 and DAAH 04-95-10308 (to J.G.H.).

\section{LITERATURE CITED}

Addessi L (1994) Human disturbance and long-term changes on a rocky intertidal community. Ecol Appl 4:786-797

Bayfield NG (1979) Recovery of four montane heath communities on Cairngorm, Scotland, from disturbance by trampling. Biol Conserv 15:165-179

Bell JD, Westoby M (1986a) Importance of local changes in leaf height and density to fish and decapods associated with seagrasses. J Exp Mar Biol Ecol 104:249-274

Bell JD, Westoby M (1986b) Variation in seagrass height and density over a wide spatial scale: effects on common fish and decapods. J Exp Mar Biol Ecol 104:275-295

Brosnan DM, Crumrine LL (1994) Effects of human trampling on marine rocky shore communities. J Exp Mar Biol Ecol 177:79-97

Brown PJ, Taylor RB (1999) Effects of trampling by humans on animals inhabiting coralline algal turf in the rocky intertidal. J Exp Mar Biol Ecol 235:45-53

Cole DN (1985) Recreational trampling effects on six habitat types in Western Montana. US Department of Agriculture, Forest Service, Intermountain Research Station, Boise, ID (Res Pap INT-350 Ogden, UT)

Cole DN (1995a) Experimental trampling of vegetation. I. Relationship between trampling intensity and vegetation response. J Appl Ecol 32:203-214

Cole DN (1995b) Experimental trampling of vegetation. II. Predictors of resistance and resilience. J Appl Ecol 32: 215-224

Cole DN, Bayfield NG (1993) Recreational trampling of vegetation: standard experimental procedures. Biol Conserv 63:209-215

Connell JH (1978) Diversity in tropical rain forests and coral reefs. Science 199:1302-1310

Connolly RM (1994) Removal of seagrass canopy: effects on small fish and their prey. J Exp Mar Biol Ecol 184:99-110

Connolly RM, Butler AJ (1996) The effects of altering seagrass canopy height on small, motile invertebrates of shallow Mediterranean embayments. PSZN I: Mar Ecol 17:637-652

Creed JC, Amado Filho GM (1999) Disturbance and recovery of the macroflora of a seagrass (Halodule wrightii Ascherson) meadow in the Abrolhos Marine National Park, Brazil: an experimental evaluation of anchor damage. J Exp Mar Biol Ecol 235:285-306
Cronquist A (1981) An integrated system of classification of flowering plants. Columbia University Press, New York

Dauby P, Poulicek M (1995) Methods for removing epiphytes from seagrasses: SEM observations on treated leaves. Aquat Bot 52:217-228

Eckrich CE (1998) Trampling effects on a seagrass assemblage: direct effects, response of associated fauna, and the role of substrate characteristics. MS thesis, University of Puerto Rico, Mayagüez

Edmond DB (1966) The influence of animal treading on pasture growth. In: International Grassld Congress. Vol 10. University of Helsinki, p 453-458

Folk RL (1974) Petrology of sedimentary rocks. Hemphill Publishing Company, Austin, TX

Goldsmith FB (1974) Ecological effects of visitors in the countryside. In: Warren A, Goldsmith FB (eds) Conservation in practice. Wiley, New York, p 217-231

Graydon D, Hanson K (1997) Mountaineering: the freedom of the hills. The Mountaineers, Seattle, WA

Harrison C (1980/1981) Recovery of lowland grassland and heathland in Southern England from disturbance by seasonal trampling. Biol Conserv 19:119-130

Hawkins JP, Roberts CM (1993) Effects of recreational scuba diving on coral reefs: trampling on reef-flat communities. J Appl Ecol 30:25-30

Heck KL, Orth RJ (1980) Seagrass habitats: the roles of habitat complexity, competition and predation in structuring associated fish and motile macro-invertebrate assemblages. In: Kennedy VS (ed) Estuarine perspectives. Academic Press, New York, p 449-464

Heck KL, Valentine JF (1995) Sea urchin herbivory: evidence for long-lasting effects in subtropical seagrass meadows. J Exp Mar Biol Ecol 189:205-217

Holm S (1979) A simple sequentially rejective multiple test procedure. Scand J Statist 6:65-70

Holmquist JG (1997) Disturbance and gap formation in a marine benthic mosaic: influence of shifting macroalgal patches on seagrass structure and mobile invertebrates. Mar Ecol Prog Ser 158:121-130

Holmquist JG (1998) Permeability of patch boundaries to benthic invertebrates: influences of boundary contrast, light level, and faunal density and mobility. Oikos 81:560-568

Holmquist JG, Powell GVN, Sogard SM (1989a) Decapod and stomatopod assemblages on a system of seagrass-covered mud banks in Florida Bay. Mar Biol 100:473-483

Holmquist JG, Powell GVN, Sogard SM (1989b) Decapod and stomatopod communities of seagrass-covered mud banks in Florida Bay: inter- and intra-bank heterogeneity with special reference to isolated subenvironments. Bull Mar Sci 44:251-262

Hylgaard T (1980/1981) Recovery of plant communities on coastal sand-dunes disturbed by human trampling. Biol Conserv 19:15-25

Jans L, Poorter L, van Rompaey RSAR, Bongers F (1993) Gaps and forest zones in tropical moist forest in Ivory Coast. Biotropica 25:258-269

Kareiva PM (1983) Local movement in herbivorous insects: applying a passive diffusion model to mark-recapture field experiments. Oecologia 57:322-327

Kay AM, Liddle MJ (1989) Impact of human trampling in different zones of a coral reef flat. J Environ Manag 13:509-520

Keough MJ, Quinn GP (1998) Effects of periodic disturbances from trampling on rocky intertidal algal beds. Ecol Appl 8: $141-161$

Kirk RE (1982) Experimental design: procedures for the behavioral sciences. Brooks/Cole Publishing Company, Monterey, CA 
Kushlan JA (1981) Sampling characteristics of enclosure throw traps. Trans Am Fish Soc 110:557-562

Leber KM (1985) The influence of predatory decapods, refuge, and microhabitat selection on seagrass communities. Ecology 66:1951-1964

Lewis FG III (1984) Distribution of macrobenthic crustaceans associated with Thalassia, Halodule and bare sand substrata. Mar Ecol Prog Ser 19:101-113

Liddle MJ (1975) A selective review of the ecological effects of human trampling on natural ecosystems. Biol Conserv $7: 17-36$

Morrisey DJ, Underwood AJ, Howitt L, Stark JS (1992) Temporal variation in soft-sediment benthos. J Exp Mar Biol Ecol 164:233-245

Pickett STA, White PS (1985) Patch dynamics: a synthesis. In: Pickett STA, White PS (eds) The ecology of natural disturbance and patch dynamics. Academic Press, San Diego, p 371-384

Rasheed MA (1999) Recovery of experimentally created gaps within a tropical Zostera capricorni (Aschers.) seagrass meadow, Queensland Australia. J Exp Mar Biol Ecol 235: 183-200

Raven P, Evert RF, Curtis H (1981) Biology of plants. Worth Publishers, Inc, New York

Rice WR (1989) Analyzing tables of statistical tests. Evolution 43:223-225

Robinson RR, Alderfer RB (1952) Run-off from permanent pastures in Pennsylvania. Agron J 44:459-462

Rozas LP, Minello TJ (1997) Estimating densities of small fishes and decapod crustaceans in shallow estuarine habitats: a review of sampling design with focus on gear selection. Estuaries 20:199-213

Schiel DR, Taylor DI (1999) Effects of trampling on a rocky intertidal algal assemblage in southern New Zealand. J Exp Mar Biol Ecol 235:213-235

Sogard SM, Powell GVN, Holmquist JG (1987) Epibenthic fish communities on Florida Bay banks: relations with physical parameters and seagrass cover. Mar Ecol Prog Ser 40:25-39

Sogard SM, Powell GVN, Holmquist JG (1989) Spatial distribution and trends in abundance of fishes residing in seagrass meadows on Florida Bay mudbanks. Bull Mar Sci 44:179-199

Editorial responsibility: Kenneth Heck Jr (Contributing Editor), Dauphin Island, Alabama, USA
Stoner AW, Lewis FG III (1985) The influence of quantitative and qualitative aspects of habitat complexity in tropical sea-grass meadows. J Exp Mar Biol Ecol 94:19-40

Sun D, Walsh D (1998) Review of studies on environmental impacts of recreation and tourism in Australia. J Environ Manag 53:323-338

Taylor KC, Reader RJ, Larson DW (1993) Scale-dependent inconsistencies in the effects of trampling on a forest understory community. J Environ Manag 17:239-248

Thayer GW, Bjorndal KA, Ogden JC, Williams SL, Zieman JC (1984) Role of larger herbivores in seagrass communities. Estuaries 7:351-376

Turner MG, Romme WH, Gardner RH, O'Neill RV, Kratz TK (1993) A revised concept of landscape equilibrium: disturbance and stability on scaled landscapes. Landsc Ecol 8: 213-227

Valentine JF, Heck KL (1991) The role of sea urchin grazing in regulating subtropical seagrass meadows: evidence from field manipulations in the northern Gulf of Mexico. J Exp Mar Biol Ecol 154:215-230

Valentine JF, Heck KL (1999) Seagrass herbivory: evidence for the continued grazing of marine grasses. Mar Ecol Prog Ser 176:291-302

Valentine JF, Heck KL, Busby JJ, Webb D (1997) Experimental evidence that herbivory increases shoot density and productivity in a subtropical turtlegrass (Thalassia testudinum) meadow. Oecologia 112:193-200

Wiens JA, Crawford CS, Gosz JR (1985) Boundary dynamics: a conceptual framework for studying landscape ecosystems. Oikos 45:421-427

Wilkinson L (1990) SYSTAT: the system for statistics. Version 5.1., SYSTAT, Inc, Evanston, IL

Williams SL (1990) Experimental studies of Caribbean seagrass bed development. Ecol Monogr 60:449-469

Wittman KJ, Ott JA (1982) Effects of cropping on the Mediterranean seagrass Posidonia oceanica (L.) Delile. PSZN I: Mar Ecol 3:151-159

Woodland DJ, Hooper JNA (1977) The effect of human trampling on coral reefs. Biol Conserv 11:1-4

Wynberg RP, Branch GM (1997) Trampling associated with bait-collection for sandprawns Callianassa kraussi Stebbing: effects on the biota of an intertidal sandflat. Environ Conserv 24:139-148

Submitted: March 30, 1998; Accepted: November 22, 1999 Proofs received from author(s): June 28, 2000 